\title{
Highly Efficient Synthesis of 2-Aryl-3-methoxyacrylates via Suzuki-Miyaura Coupling Reaction ${ }^{\dot{ }}$
}

\author{
Hyung Ho Kim, Chun Ho Lee, Young Seob Song, No Kyun Park, Bum Tae Kim, and Jung-Nyoung Heo" \\ Bioorganic Science Division, Korea Research Instinte of Chemical Technology, Daejeon 305-600. Korea \\ "E-mait: heoin(akrict,rekr \\ Received December 6, 2005
}

Key Words : Suzuki reaction, Palladium, Boronic acid, Methoxyacrylate, Fungicide

The Suzuki-Miyaura coupling reaction provides a convenient access to the carbon-carbon bond formation with high efficiency.' Recently, a number of 2-aryl-3-methoxyacrylates served as a key scaffold for the development of biologically active pharmaceuticals ${ }^{2}$ and agrochemicals ${ }^{3}$ (Figure 1). Especially, the discovery of the naturally-occurring fungicides, such as strobilurin $A(1)$ and oudemansin $A$ (2), possessing a $\beta$-methoxyacrylate moiety was immediately seized great attention by industrial research groups to open a new era of the strobilurin family including azoxystrobin $(3)^{4}$ and picoxystrobin (4)..$^{5}$

Although a plethora of methods has been established on the development of the Suzuki-Miyaura reaction of aryl (including heteroaryl) halides or triflates, the cross-coupling reaction of vinyl halides, in particular of $\alpha$-halo- $\beta$-methoxyacrylate, remains an attractive area for investigation. In the event, we envisioned a systematic study of this type of the reaction with various halo-substituted arylboronic acids.

The required arylboronic acids $6 \mathbf{6}-\mathbf{d}$ were easily prepared by following the literature method, ${ }^{7}$ in which selective lithium-bromide exchange followed by in situ quenching with borate offered a high yielding procedure (Scheme 1). Next, $\alpha$-iodo- $\beta$-methoxyacrylate 8 was conveniently synthesized via sequential iodonation and base-mediated elimination reactions of the corresponding $\beta$-methoxyacrylate $7 .{ }^{*}$ Alternatively, 8 was also prepared vio an in situ method using iodine in pyridine without loss of yields."<smiles>COC=C(C(=O)OC)/C(C)=C\C=C\c1ccccc1</smiles>

Strobilurin A (1)

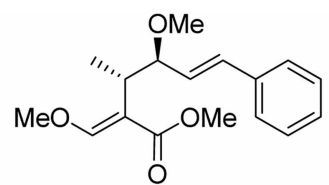

Oudemansin A (2)<smiles>CO/C=C(/C(=O)OC)c1ccccc1COc1cc(Oc2ccccc2C#N)ncn1</smiles><smiles>COC(=O)OCCOc1cccc(C(F)(F)F)n1</smiles>

Figure 1. Biologically active molecules having a p-methoxyacrylate moiety.

Dedicaled to Prof. Bong Young Chung on the occasion of his 61 st birthday.

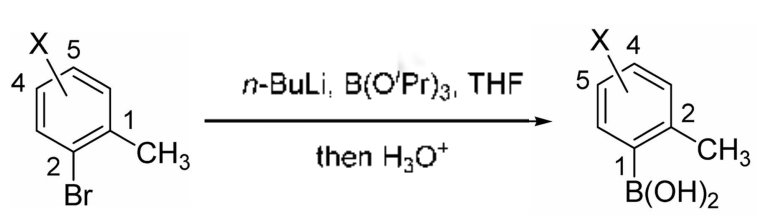

$$
\begin{aligned}
& \mathbf{5 a}, X=H \\
& \mathbf{5 b}, X=5-F \\
& \mathbf{5 c}, X=4-F \\
& \mathbf{5 d}, X=5-C l
\end{aligned}
$$

6a, $X=H, 90 \%$

6 b. $X=4-F, 87 \%$

6c, $X=5-F, 78 \%$

$6 \mathrm{~d}, \mathrm{X}=4-\mathrm{Cl}, 88 \%$

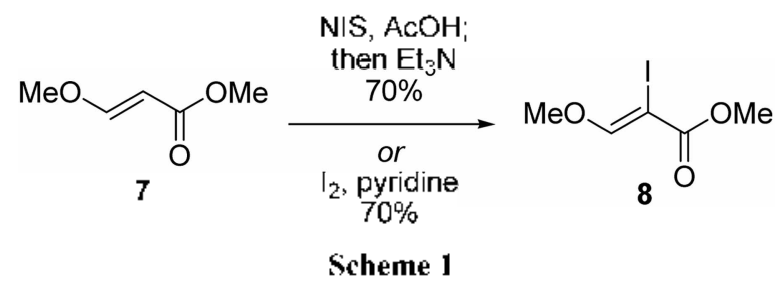

Subsequently, we examined the Suzuki-Miyaura reaction of $\alpha$-iodo- $\beta$-methoxyacrylate 8 with 5 -fluoro-2-methylphenylboronic acid $\mathbf{6 c}$ in the presence of a suitable palladium catalyst. As illustrated in Table 1, our initial attempt was focused on the use of $\mathrm{Pd}\left(\mathrm{PPh}_{3}\right)_{4}(4 \mathrm{~mol} \%)$ in combination with $\mathrm{Na}_{2} \mathrm{CO}_{3}\left(2.0\right.$ equiv) in $\mathrm{DMF} / \mathrm{H}_{2} \mathrm{O}$ at 70 " $\mathrm{C}$ for $20 \mathrm{~h}$ (entry 1$)$. This reaction provided 2-(5-fluoro-2methylphenyl)-3-methoxyacrylate $9 \mathrm{c}$ in $22 \%$ yield. As a next step, we screened a range of co-solvent systems such as toluene/ $/ \mathrm{E}$ tOH$/ / \mathrm{H}_{2} \mathrm{O}$. THH $/ \mathrm{I}_{2} \mathrm{O}$ and dioxane $/ \mathrm{I}_{2} \mathrm{O}$ to find out the solvent effects (entries 2-4). ${ }^{10}$ The results obtained from reactions using the co-solvents system other than dioxane/ $\mathrm{I}_{2} \mathrm{O}$ turned out to be inferior. When a base was changed from $\mathrm{Na}_{2} \mathrm{CO}_{3}$ to $\mathrm{K}_{2} \mathrm{CO}_{3}$, the reaction yield was slightly increased (entry 3). Meanwhile, the use of $\mathrm{K}_{3} \mathrm{PO}_{4}$ in combination with a $\mathrm{T}] \mathrm{IF} / \mathrm{I}_{2} \mathrm{O}$ system remarkably improved the reaction yield up to $86 \%$ in a shortened reaction period (entry 4). Finally, we were delighted to find the optimum conditions using $\mathrm{K}_{3} \mathrm{PO}_{4}$ in dioxane $/ \mathrm{H}_{2} \mathrm{O}$ to furnish $9 \mathrm{c}$ in $96 \%$ yield (entry 5 ).

Using the optimized reaction conditions (Table l, entry 5), we performed the Suzuki-Miyaura reaction of $\alpha$-iodo- $\beta$ methoxyacrylate 8 with a variety of halo-substituted phenylboronic acids 6a-d. As illustrated in Table 2, we obtained the coupling products 9 a-d in excellent yields. ${ }^{.1}$

With the successful demonstration of Suzuki-Miyaura reaction for the synthesis of 2-aryl-3-methoxyacrylates 9 , we further explored the preparation of biologically interesting molecules. Therefore, we attempted transformation of 9d 
Table 1. Suzuki-Miyautra reaction of $\alpha$-iodo- $\beta$-methoxyacrylate 8 with 5-fluoro-2-methylphenylboronic acid $6 \mathrm{c}^{\prime \prime}$

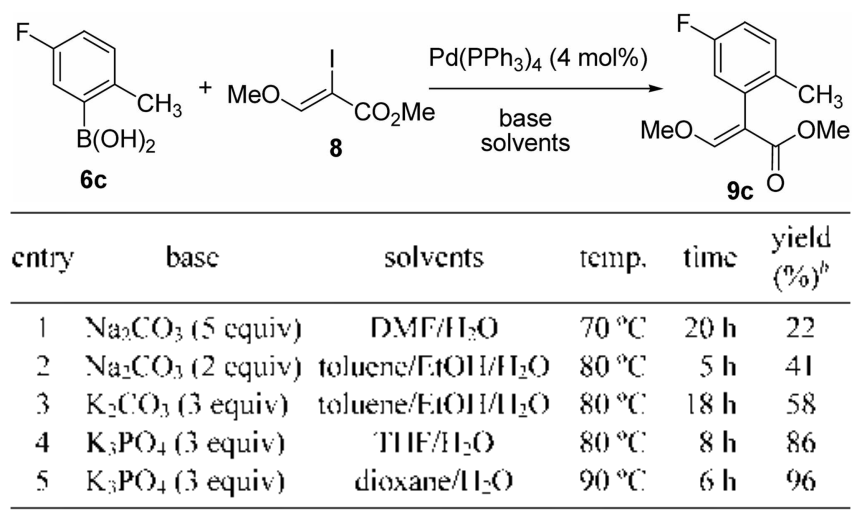

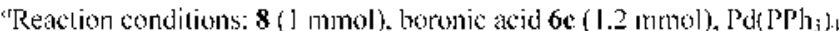

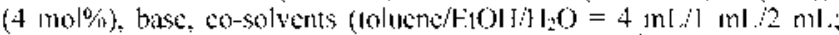

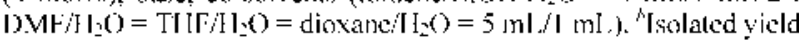

Table 2. Suzuki-Miyaura reaction of $\alpha$-iod $\alpha-\beta$-methoxyacrylate 8 with arylboronic acids $6^{\prime \prime}$

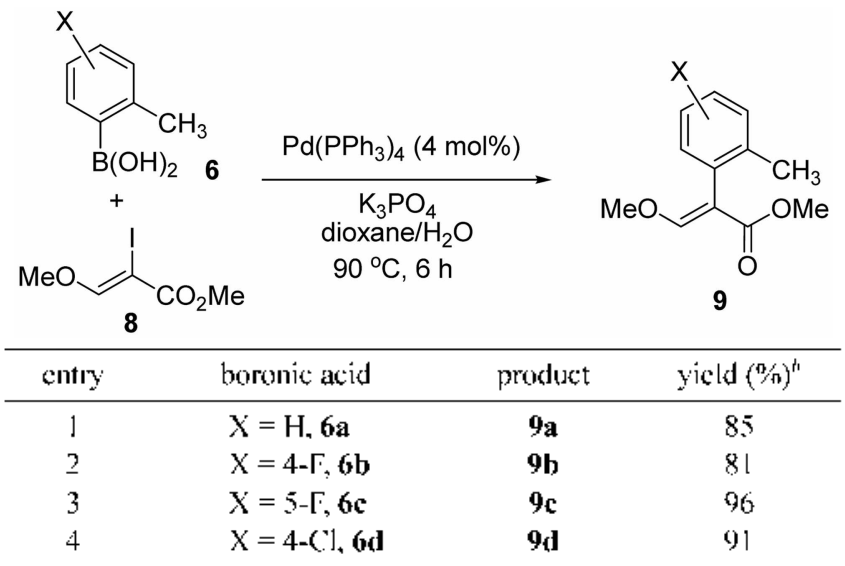

"Reaction conditions: 8 (l mmol), $\left.6(1.2 \mathrm{~mm} n)), \mathrm{Pd}\left(\mathrm{PPh}_{3}\right)_{+}(4 \mathrm{~mol}) \%\right)$, $\mathrm{K} ; \mathrm{PO}_{1}(3,0 \mathrm{mmol})$, dioxane $\mathrm{I} \mathrm{HO}(5 \mathrm{~mL} / \mathrm{mL}), 900^{\circ} \mathrm{C}, 6 \mathrm{~h}$. "Isolated vicld.<smiles>COC=C(C(=O)OC)c1ccc(Cl)cc1C</smiles>

9d

$74 \%$<smiles>C[R4]([O-])([O-])[O-]</smiles>

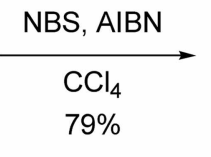

OBn

11
Scheme 2

with $N$-bromosuecinimide (NBS) to obtain benzyl bromide 10 in $79 \%$ yield (Scheme 2). Then, 10 was coupled with 4benzyloxyphenol in the presence of $\mathrm{K}_{2} \mathrm{CO}_{3}$ to furnish aryl benzyl ether 11 in good yield.

In conclusion, we have developed a highly efficient and convergent synthesis of 2-aryl-3-methoxyacrylates via the Suzuki-Miyaura coupling reaction of $\alpha$-iodo- $\beta$-methoxyacrylate 8 with arylboronic acids 6 . The biological activities of 2-aryl-3-methoxyacrylate derivatives will be reported in due course.

Acknowledgement. We thank Korea Research Institute of Chemical Technology (KK-0501-G0) and the Center for Biological Modulators (CBM2-A100-001-2-1-0) for the support of this work.

\section{References}

I. For reviews, see: (a) Bellina, F.; Cappita, A.: Rossi, R. Synthesis 2004, 2419. (b) Hassan, J.; Sevignon, M.; Gozzi. C.; Schulz, E.; Leinaire, M. Chem. Rev 2002, 102, 1359. (c) Kotha, S.; Lahiri, $\mathrm{K}$; Kashinath, D. Tetrahedron 2002, 58, 9633. (d) Suzuki, A, J. Organomet. Chemt 1999, 576, 147. (e) Miyaura, V.; Suzuki, A. Chent Rev. 1995, 95, 2457.

2. (a) Alzeer, I.; Chollet, J.; Heinze-Krauss, I; Hubschwerlen, C.; Matile, H.; Ridley, R. G. J. Med. Chem. 2000, \{3, 560. (b) Uchiro, H.; Nagasawa, K.; Kotake, T.; Hasegawa, D.; Tomita, A.; Kobayashi, S. Bioorg. Med. Chtm. Lttt. 2002, /2, 2821.

3. For reviews, see; (a) Bartlett, D. W.; Clough, J, M.; Godwin, J. R.; I Jall, A. A.; lamer, M.: Parr-Dobr/anski. B. Pesf Manag. Sci. 2002, 5, 649. (b) Sauter, H.; Steglich, W. Anke, 'T. Angen: Chem. Int. Ed. 1999. 38, 1328. (c) Song. Y. S.; Sung, V.-D.; Yu. Y. M.; Kim, B. T. Bull. Korean Chem. Serc. 2004, 25, 1313.

4. Godfrey, C. R. A.; Strecting. I, T.; Chectham, R. Г.P-A 382375 , 1989 .

5. C.lough, J. M.; Godlrey, C.. R. A.; De Fraine, P. J.; I lutchings, M. (i) Anthony, V. M. U.S. Patent 5,021,581, 1992.

6. (a) Rossi, R.; Bellina, F.; Carpita, A. Sintett 1996, 356. (b) Hodgson, D. M.; Witherington, I.; Moloney, B. A.; Richards, I. C; Brayer, J.-I. Sinteft 1995, 32. (c) 7icgler, II:; Neff, D.; Stutz, W. U.S. Patent 5.726,343, 1998. (d) Rossi, R.; Carpita, A.; Ribecai, A.; Mannina, I. Tetrabedron 2001, 57. 2847.

7. Li, W.; Nelson, D. P.; Jensem. M. S. Hoemer, R. S.; Cai, D.; Larsen, R. D.: Reider. I’. J. J. Org. Chem. 2002, 67, 5394.

8. Kowalski, C. 1.: Weber, A. E.; Fields, K. W. J. Org. Chem. 1982, 47,5088 .

9. Johnson, C. R.; Adams, I. P.; Braun. M. P.; Senanayake, C.. B. W.; Wovkulich. [. M.; Uskokovic, M. R. Tetrahedron Letr. 1992, 33. 917.

10. Song, Y. S.; Kim, B. I;; Heo, J.-. . Ferrahedron Lett. 2005, 46. 5987.

11. Generd procedure. To a tlask was added $x$-iodo- $\beta$-methoxyacrylate 8 ( $1 \mathrm{mmol}$ ). $\mathrm{Pd}\left(\mathrm{PPh}_{3}\right)_{+}(4 \mathrm{~mol} \%$ ), arylboronic acid 6 ( 1.2 mimol), and $\mathrm{K}_{3}\left[\mathrm{O}_{+}(3,0\right.$ mmol) sequentially. The mixlure was dissolved in dioxane $/ \mathrm{H}_{2} \mathrm{O}(5 \mathrm{~mL} / \mathrm{mL})$ and degassed with argon over 5 min. Then, the reaction mixture was stired a1 $90^{\circ} \mathrm{C}$ for $6 \mathrm{~h}$. After cooled to rt, the mixture was diluted with EtOAc and washed with $\mathrm{Hl}_{2} \mathrm{O}$ and brine solution. The organic layer was dried over $\mathrm{MeSO}_{+}$and concentrated in vacto and the residue was purifled by silica gel flash column chromatography ( $10 \% \mathrm{EtOAC}$ hexanes). Data for 9d: $\operatorname{mp} 65-72$ " $\mathrm{C}$; $\mathrm{H}$ NMR (500 $\left.\mathrm{MH} \angle, \mathrm{CDCl}_{3}\right)$ $07.56(\mathrm{~s}, \mathrm{IH}), 7.21$ (d, $1 \mathrm{H}, J=5.1 \mathrm{H} z, 3.6 \mathrm{H}<$ ), 7.15 (dd, $1 \mathrm{H}, J=$ $4.9 \mathrm{~Hz}, 1.3 \mathrm{~Hz}$ ). 7.03 (d. IH, $J-4.9 \mathrm{~Hz}$ ) 3.83 (s, $3 \mathrm{H}), 3.70$ (s,

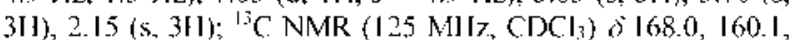
$139.5,133.5,132.1,130.9,130.0,125.8,110.4,62.2,51.9,19.8$; $\mathrm{MS}(\mathrm{Fl}) \mathrm{m} / \mathrm{z} \mathrm{M}^{-}$for $\mathrm{C}_{12} \mathrm{H}_{13} \mathrm{ClO}$, calc. 240.055 , found 241.95 (14). $239.95\left(\mathrm{M}^{-}, 42\right), 207.94(41), 148.95(41), 129.01(45), 115.01$ (38), $103.01(43), 75,01(100)$. 